\title{
Predict-Observe-Explain Tasks in Chemistry Laboratory: Pre-Service Elementary Teachers' Understanding and
}

\author{
Attitudes
}

\author{
Burçin ACAR ŞEŞEN*
}

Ayfer MUTLU*

\begin{abstract}
This study was conducted to investigate the effects of laboratory activities based on predictobserve-explain tasks related to the subjects of "Mixtures, Physical and Chemical Changes, Acids and Bases" on pre-service elementary teachers' understanding and attitude toward chemistry lesson and chemistry laboratory. For this purpose, the pre-service elementary teachers were randomly assigned to experimental $(\mathrm{N}=26)$ and control $(\mathrm{N}=30)$ groups. The experimental group was instructed using laboratory activities based on predict-observe-explain task and the control group was taught using traditional cook-book design laboratory activities during ten weeks. For the data collection, a two-tier concept test, attitude toward chemistry lesson scale and attitude toward chemistry laboratory scale were applied before and after the instructions. The results indicated that the pre-service elementary teachers who were trained using laboratory activities based on predictobserve-explain task had significantly higher scores in terms of achievement and attitude toward chemistry lesson and laboratory than those taught by the traditional approach. It was also found that instruction for laboratory activities based on predict-observe-explain task was more successful in remediation of the predetermined alternative conceptions.
\end{abstract}

Keywords: Acids and bases, attitude toward chemistry lesson and chemistry laboratory, conceptual understanding, mixtures, physical and chemical changes, predict-observe-explain.

\section{Kimya Laboratuvarında Tahmin-Gözlem-Açıklama Uygulamaları: Sınıf Öğretmeni Adaylarının Anlamaları ve Tutumları}

Öz

Sunulan çalışmada "Karışımlar, Fiziksel ve Kimyasal Değişim, Asitler ve Bazlar" konularında tahmin gözlem açıklamaya dayalı laboratuvar etkinliklerinin sını öğretmeni adaylarının anlamalarına ve kimya dersine ve kimya laboratuvarına karşı tutumlarına etkisinin incelenmesi amaçlanmıştır. Bu amaçla sınıf öğretmeni adayları deney $(\mathrm{N}=26)$ ve kontrol $(\mathrm{N}=30)$ gruplarına ayrılmıştır. Laboratuvar etkinlikleri on hafta süresince deney grubunda tahmin gözlem açıklamaya dayalı olarak ger-

\footnotetext{
* Doç. Dr., İstanbul Üniversitesi, bsesen@istanbul.edu.tr

** Yrd. Doç. Dr., Kırklareli Üniversitesi, ayfermutlu@klu.edu.tr
} 
çekleştirilirken, kontrol grubu geleneksel yaklaşıma dayalı yürütülmüştür. Veri toplama aracı olarak iki aşamalı kavram testi, kimya dersine karşı tutum ölçeği ve kimya laboratuvarına karşı tutum ölçeği kullanılmıştır. Sonuçlar tahmin gözlem açıklamaya dayalı laboratuvar etkinlikleri yapan sınıf öğretmeni adaylarının geleneksel yaklaşıma dayalı etkinlikler gerçekleştirenlere kıyasla başarı, kimya dersine ve kimya laboratuvarına karşı tutum açısında istatistiksel olarak anlamlı düzeyde daha yüksek puana sahip olduklarını göstermiştir. Ayrıca tahmin gözlem açılamaya dayalı laboratuvar etkinliklerinin çalışmanın öncesinde belirlenen alternative kavramları gidermede oldukça başarılı olduğu bulunmuştur.

Anahtar Kelimeler: Asitler ve bazlar, fiziksel ve kimyasal değişim, kavramsal anlama, karışımlar, kimya dersine ve kimya laboratuvarına karşı tutum ölçeği, tahmin-gözlem-açıklama.

\section{INTRODUCTION}

Laboratory instruction has been a central part of science education from the early 20th century (Singer, Hilton \& Schweingruber, 2006). A laboratory setting gives students a chance to work in small groups and to investigate scientific phenomena. By working in a laboratory, it is ensured that students - learn, clarify and validate scientific principles and theories. Hofstein and Lunetta (2004) have argued that laboratory has an important role for students' conceptual understanding. Costu, Ayas and Niaz (2010) have also indicated that chemistry laboratory provides students an opportunity to observe scientific events and it also enhances conceptual understanding and conceptual change. Furthermore, it has been emphasized that laboratory work is very important to promote positive attitudes, to increase interest, and to motivate students to learn science and especially chemistry (Freedman, 1997; Hofstein \& Lunetta, 2004; Thompson \& Soyibo, 2002). Students enjoy laboratory work; this is why laboratory experiences are important for developing positive attitudes and interest in science (Hofstein \& Lunetta, 2004).

Besides students' having opportunities in laboratory an environment, it has been discussed that students can enhance their conceptual understanding and positive attitudes, if laboratory activities are carried out in an appropriate manner. In a traditionally cookbook laboratory setting, students only follow the directions given and the experimental procedure. Students concentrate on following recipes, collecting and recording data in the laboratory guide which is including list of tasks for students in the environment. Therefore they aim only to complete their task and the purpose of their investigation is not understood in depth by them (Hofstein \& Lunetta, 2004). In addition to these, excessive details given in the cook-book laboratory guides can distract students from the purpose of experiment (Johstone \& Wham, 1982). Moreover, students rarely discuss scientific facts related to their investigation (Roth, 1994). They can only verify these facts to follow their tasks without any opportunities to reason about their observations. However, laboratory activities should involve students' active participation (Bradley, 2001). According to Milner, Ben-Zvi and Hofstein (1987), students wanted more advanced chemistry courses because they were able to gain experience with participation of these practical activities in the chemistry laboratory. While students experimenting, they should not only conduct laboratory activity step by step and collect data, but also they should discuss the observed data by correlating their conceptual learning. When the degree of active participation in the science laboratory improves, attitudes towards chemistry learning and chemistry laboratory increase (Okebukola, 1986).

Daily life application in the laboratory is also one of the most important factors which promote conceptual understanding and positive 
attitudes. If laboratory activities do not associate with students' everyday life applications and social problems, they will not be able to make a connection between scientific facts and their experiences, so this situation will influence their achievements (Costu, Unal \& Ayas, 2007), attitudes and interests (Hofstein \& Mamlok-Naaman, 2011). Also, students' interests in the subject contribute to studying of science (Lindahl, 2003) and this can be provided by giving subjects from daily life examples. Because, when students are familiar with the subjects from their previous experience, they feel confident enough and this situation affects their motivation (Hofstein \& Mamlok-Naaman, 2011).

Laboratory activities have been a substantial way for activity/performance-based science tasks (Acar-Sesen \& Tarhan, 2013). A laboratory instruction based on active learning methods provides students an opportunity to analyze problems by using hands-on and inquiryoriented activities in cooperative learning groups (Abdullah, Mohammed \& Hj Ismail, 2009). Therefore, science educators have focused on sufficiency of cook-book laboratory settings for educational goals and they have highlighted the effectiveness of using active learning methods in laboratory instructions. In the previous research, different learning methods and techniques were used in the laboratory for increasing students' achievement, promoting students' understanding and improving their attitude toward chemistry lesson and chemistry laboratory. Predict-Observe-Explain (POE), which is used in the laboratory setting, is one of these active learning techniques.

\subsection{Predict-Observe-Explain}

POE has been used to provide students an opportunity to predict the result of the situation with its reasons and it also ensures students observe the situation and do explanations to remove the conflict between prediction and observation (Kose, Costu \& Keser, 2003). In the POE procedure, hypothesis are formulated, reasons are given to prove these hypothesis and then related data is collected and results are discussed (White, 1988). POE is an efficient strategy for encouraging students to discuss about their ideas (White \& Gunstone, 1992). The POE technique is completed by requiring students to carry out three tasks.

In the Predict $(P)$ step, information about an experiment or event is given to students and the students are supposed to predict the outcome of this event or situation. They have to justify, inquiry and give a reason for their prediction (White \& Gunstone, 1992). In this step, the students' understanding and alternative conceptions are identified while they are discussing on their task in their cooperative groups. Moreover, the prediction stage provides students an opportunity to focus on observation and it promotes motivation.

The students describe what they see in the Observe (O) step. This may be an experiment, an event or a video related to the learning issue. These activities should be easy for observation and they should constitute a conflict (White \& Gunstone, 1992).

In the Explain (E) step, the students inquire differences between their prediction and observation in order to reconcile any conflict between their prediction and observation. The students discuss and share their explanations. In this way, they do not repeat the knowledge in books; they can explain the phenomenon with their own sentences.

POE tasks have been reported extensively in the literature. Although POE tasks have been used in studies of conceptual change and learning achievement, there has been lack of studies that investigate the effect of POE on under- 
graduates' attitudes towards chemistry lesson and chemistry laboratory. Also, elementary education has major importance for effective chemistry education in high school and undergraduate level. Therefore it should be provided that elementary teachers have positive attitude toward chemistry lesson and chemistry laboratory and they should understand meaningfully basic chemistry concepts such as mixtures, physical and chemical changes, acids and bases for providing effective learning to their students. Research which investigated understanding of aforementioned concept in elementary teacher training level has been limited.

Liew and Treagust (1998) aimed to explore the effectiveness POE in diagnosing students' understanding of science and in identifying their level of achievement. The POE tasks were concerned with expansion of water, solubility of salt, power and resistance of light globes. They collected data from $11^{\text {th }}$ grade students included their written responses in POE task worksheet, interviews with individual students, and in-class discussion. The results implied that POE task can be used to design learning activities insightfully which starts with the students' viewpoints rather than teachers' or scientists'. They also reported that POE tasks are effective in facilitating the teacher and the students in documenting student achievement and profiling student progress.

Hsu (2004) explored students' alternative conceptions of combustibility by using the POE technique. Research participants were $966^{\text {th }}$ graders, $868^{\text {th }}$ graders and $12111^{\text {th }}$ graders. Research findings indicated that over half of the students in each grade predicted the hydraulic oil as a combustible substance. After the observation, over twenty percent of the students in each grade still thought that the hydraulic oil was combustible and about one third of the students considered the occurrence of smoke as burning. At the explanation stage, most of the students could not explain that with scientific reasons and some of the students, who predicted that the hydraulic oil was combustible, thought either the temperature was not high enough or the boiling point of the hydraulic oil was too high to cause combustion.

Bilen and Aydogdu (2010) aimed to investigate the effects of a laboratory instruction, based on POE, on the pre-service science teachers' conceptual understanding of photosynthesis and respiration in plants. They also studied on the pre-service science teachers' attitudes towards general biology laboratory. The research was conducted with participation of 122 the preservice elementary teachers who took the General Biology Laboratory course. A two-tier concept test related to photosynthesis and respiration in plants and an attitude scale toward biology laboratory were used for data collection. Their finding showed that laboratory instruction designed based on POE strategy was an effective way of promoting the conceptual understanding and improving attitudes toward biology laboratory positively.

Costu, Ayas and Niaz (2010) developed a POE based laboratory instruction described as Predict-Discuss-Explain-Observe-DiscussExplain (PDEODE). They found that this technique was effective in achieving better conceptual understanding of evaporation concept. In their other study, they used the same procedure to teach condensation concepts and they found that PDEODE strategy was also effective in promoting the understanding of condensation concepts (Costu, Ayas \& Niaz, 2012).

Acar-Sesen (2013) investigated that the preservice science teachers' understanding of surface tension, cohesion and adhesion forces by using computer-mediated predict-observeexplain tasks. So, three computer-mediated predict- observe-explain tasks were devel- 
oped. The pre-service science teachers' written POE task responses were analyzed to investigate their understanding. It was found that computer-mediated predict-observe-explain task was an effective method to diagnose students' understanding.

Bilen and Kose (2012) investigated the effects of activities, based on POE, about growth and development in plant on pre-service science teachers' attitudes toward science teaching. They studied with seventy-four second grade the pre-service science teachers and POE activities were conducted in the experimental group and a teacher centred traditional approach in the control group. The results showed that there were significant differences between the experimental and the control groups' attitudes toward science teaching in favour of the experimental group. Moreover, the pre-service science teachers said that POE activities were effective, they were happy, they felt themselves better, their self-confidence increased and they would use these activities in their lessons.

Koseoglu, Tumay and Kavak (2002) developed a POE activity named as "Water can be boiled with ice" This activity was applied to forty-four the pre-service chemistry teachers. They collected data from observations and interviews. According to the results, they found that POE activity was effective in promoting the preservice science teachers' attitudes toward chemistry, their interest and motivation.

An extensive study has also been done by Yavuz and Celik (2013). They used POE tasks concerned with gases subject in the context of general chemistry lesson to remedy the preservice elementary teachers' alternative concepts and to promote their attitude toward chemistry lesson. A gases concept test, an attitude scale toward chemistry and POE worksheets were used for data collection. Eight POE activities were applied during three weeks in the experimental group and gases subject was taught with traditional approach in the control group. Researchers found that POE was an effective way of promoting the pre-service elementary teachers' achievement, conceptual understanding on gases subject and their attitude toward chemistry.

\subsection{Purpose of the Research}

The purpose of this study was to investigate the effects of the laboratory activities, which are based on predict-observe-explain tasks, on the pre-service elementary teachers' understanding some chemistry concepts, their attitudes toward chemistry lesson and attitudes toward chemistry laboratory. For this reason, the following research questions were investigated;

1. Do the laboratory activities based on predict-observe-explain task contribute to better conceptual understanding of chemistry concepts?

2. Do the laboratory activities based on predict-observe-explain task affect the preservice elementary teachers' attitude toward chemistry lesson?

3. Do the laboratory activities based on predict-observe-explain task affect the preservice elementary teachers' attitude toward chemistry laboratory?

\section{METHOD}

\subsection{Participants}

This study was conducted with participation of 56 the pre-service elementary teachers enrolled in Science and Technology Laboratory Applications-II lesson in an education faculty in Istanbul, Turkey. They were randomly assigned to experimental $\left(\mathrm{N}_{\mathrm{E}}=26\right)$ and control $\left(\mathrm{N}_{\mathrm{C}}=30\right)$ groups. All the pre-service elementary teachers in both groups were similar in socioeconomic 
status; a great majority of the pre-service elementary teachers were from middle-class families. They all achieved Science and Technology Laboratory Applications-I lesson in previous semester. They had also learned laboratory rules, laboratory safety, and laboratory methods in advance.

\subsection{Instruments}

\subsubsection{Two-tier concept test}

In this study a two-tier concept test (TTCT), consisted of 23 items related to the concepts such as "Mixtures, Physical and Chemical Changes, Acids and Bases", was developed based on following Treagust's methods (1988) by the researchers for data collection. Prior to the development of the tests items, the content boundaries had been defined by the researchers. Multiple-choice items with an open ended part included 23 items, in which the students were required to explain their reasons for their answers to the first part, were constructed. The test was validated by three chemistry educators and it was applied to 62 the pre-service elementary teachers. The responses of the open-ended part of each item were analyzed and alternative conceptions were determined. Distracters were constructed by considering the students' responses to the open-ended part and alternative concepts identified in the literature (e.g. Ayvaci \& Coruhlu, 2009; Calik \& Ayas, 2005; Demirci et. al., 2005; Hesse \& Anderson, 1992; Krause \& Tasooji, 2007; Schmidt, 1991; Sheppard, 2006; Toplis, 1998). Later, the two-tier diagnostic test was developed in which the first tier was the conventional multiple choice step and the second tier was the part in which there were possible reasons for the answers given to the first tier. The second tier included two, three, four or five responses, one of them was the expected answer. The test was piloted with participation of 102 undergraduates, and then item analysis and reliability analysis were made. For analyzing data, the answer was considered to be correct if both tiers were correctly answered (Treagust, 1988). Therefore one point was given for the items only when both parts of the items were correctly answered, and zero point was given for the items when either part was incorrectly answered. The final version of the test included 23 items and reliability coefficients were found to be 0.72 . An example item related to strength of acids is presented in Table 1.

Table 1. A sample question from the two-tier test

A. Indicators
B. pH meter
C. The percentage of dissociation in water
D. Melting proportion to metals
Because;
I. Acids turn indicators to red colour.
II. pH is less than 7.
III. Acids don't keep metal chemical storage box.
IV. Weak acids dissociate partially.

\subsubsection{Attitude toward chemistry lesson scale}

To determine the pre-service elementary teachers' attitudes toward the chemistry lesson before and after the instruction, 5-point Likert type Attitude toward Chemistry Lesson Scale (ATCS) developed by Acar (2008) in which twenty five items was used. Before development of the items, the literature related to the 
attitude toward science and chemistry had been reviewed (Berberoglu \& Calikoglu, 1992;

Freedman, 1997; Hofstein \& Lunetta, 1982;
Koballa, 1988; Koballa, Crawley \& Shrigley, 1990; Salta \& Tzougraki, 2004).

Table 2. ACTS' dimensions, items and cronbach's alpha reliability coefficient

\begin{tabular}{lcc}
\hline \multicolumn{1}{c}{ Dimensions } & Items & Cronbach Alpha reliability coefficients \\
\hline Interest in chemistry lesson & $1,3,8,18,20,22$. & 0.78 \\
Understanding and learning chemis- & $2,5,7,12-15,17$, & 0.84 \\
try & 21,23 & \\
$\begin{array}{l}\text { The importance of chemistry in real } \\
\text { life }\end{array}$ & $4,6,11,19,25$ & 0.83 \\
Chemistry and occupational choice & $9,10,16,24$ & 0.87 \\
\hline
\end{tabular}

The items were constructed by considering the attitude scale developed by Salta and Tzougraki (2004). For the validity, the scale was reviewed by seven educators from different universities. After the corrections, the scale was applied to 195 undergraduates for the reliability. Cronbach's alpha reliability coefficient was found to be 0.82 . The ATCS has four dimensions as it can be seen in Table 2.

\section{Attitude toward chemistry laboratory scale}

Students' attitudes toward the chemistry laboratory before and after the instruction were

Table 3. ACLTS' dimensions, items and cronbach's alpha reliability coefficient

\begin{tabular}{lcc}
\hline \multicolumn{1}{c}{ Dimensions } & Items & Cronbach Alpha reliability coefficients \\
\hline Laboratory environment and using & $1,6,9,13$ & 0.82 \\
equipments & & 0.90 \\
Experimental process in the laboratory & $2-8,10,12,23,25$ & 0.85 \\
Assessment in the laboratory & $11,15-21,26$ & 0.87 \\
Cooperative learning in the laboratory & $14,22,24,27$ & \\
\hline
\end{tabular}

determined by using 5-point Likert type Attitude toward Chemistry Laboratory Scale (ATCLS) developed by Tarhan (2008). Before development of the items, the literature reviews had been done (Carlo \& Bodner, 2004; Freedman, 1997). For the validity, the scale was reviewed by seven educators from different universities. It was applied to 283 undergraduates; Cronbach's alpha reliability coefficient was found to be 0.87 . The ATCLS has four dimensions (Table 3).

\subsection{Data Analysis}

For the two tier diagnostic test's reliability analysis, SPSS data file was constructed. While analysing these data, the answer was considered to be correct if both tiers were correctly answered (Treagust, 1988) because of its decreasing students' obtaining a correct answer by chance (Tsui \& Treagust, 2010) and evaluating meaningful understanding, deeply. Therefore, one point was given for items only when both parts of the item were correctly answered, and zero point was given for items when either part was incorrectly answered. Cronbach's alpha reliability coefficient was reported because coefficient alpha is equivalent to the 
Kuder-Richardson 20 coefficient for dichotomous data (Green \& Salkind, 2005).

For calculating the pre-and post TTCT total score, one point was given for items only when both parts of the item were correctly answered, and zero point was given for items when either part was incorrectly answered. For evaluating the pre-service elementary teachers' understanding, their responses to each item were analysed by following Treagust method (1988). Therefore, the percentage of the pre-service elementary teachers' choices for each option was calculated. Alternative conceptions that had percentage more than $20 \%$ related to aforementioned concepts were reported.

An example item related to acids-bases was presented to illustrate how the item worked and how the data was used by the pre-service elementary teachers.

When you examine a $\mathrm{pH}$ scale, you can see that $\mathrm{pH}$ is between $0-14$. So, this $\mathrm{pH}$ value;

a) It is the measure of acid strength.

b) It is always 7 after the neutralization.

c) It is the measure of concentration.
Because:

A) $\mathrm{pH}$ and $\mathrm{H}_{3} \mathrm{O}^{+}$are inversely proportional.

B) Acid strength increases when $\mathrm{pH}$ is close to 1.

C) After all the neutralization, neutral solutions are always formed.

D) Acid strength increases when $\mathrm{pH}$ increases.

This item assessed the pre-service elementary teachers' understanding of acids' strength and how determined to this conclusion. While analysing this item, the percentages of each option having been chosen in both tiers were calculated (Table 4).

In the pre-test, the minor part of the pre-service elementary teachers (19\%) responded correctly that $\mathrm{pH}$ is the measure of concentration. Also, very few of the pre-service elementary teachers $(13 \%)$ correctly responded to the second tier. However, only $8 \%$ of participants selected correct choice that was $\mathrm{c}$ in the first tier and $\mathrm{A}$ in the second tier, so only $8 \%$ correctly understood $\mathrm{pH}$ concept and the relationship between $\mathrm{pH}$ and concentration. The majority of the preservice elementary teachers chose a and C, $64 \%$ and $40 \%$, respectively.

Table 4. Analysing of an item related to acids-bases for identifying experimental group's understanding for pre-test

\begin{tabular}{|c|c|c|c|c|c|c|}
\hline \multirow{2}{*}{$\begin{array}{l}\mathrm{N} \\
151\end{array}$} & \multirow{2}{*}{ First Tier (\%) } & \multicolumn{5}{|c|}{ Second Tier (\%) } \\
\hline & & $\mathrm{A}$ & B & $\mathrm{C}$ & $\mathrm{D}$ & No reason \\
\hline & $\mathrm{a}(64 \%)^{* *}$ & $10 \%$ & $17 \%$ & $23 \%$ & $14 \%$ & $0 \%$ \\
\hline & b $(17 \%)$ & $0 \%$ & $2 \%$ & $15 \%$ & $0 \%$ & $0 \%$ \\
\hline & с $(19 \%)$ & $8 \% *$ & $0 \%$ & $2 \%$ & $4 \%$ & $5 \%$ \\
\hline & No choice $(0 \%)$ & - & - & - & - & - \\
\hline Total & & $18 \%$ & $19 \%$ & $40 \%$ ** & $18 \%$ & $5 \%$ \\
\hline
\end{tabular}

Note ${ }^{*}$ The correct choice and reason response

** Reported alternative conceptions that had percentages more than $20 \%$

- No responses in this category
According to the results, these the pre-service elementary teachers had following alternative conceptions; 
- $\mathrm{pH}$ is the measure of acid strength (64\%).

- Neutral solutions are always formed in all neutralization reactions (40\%).

For statistical analysis of ATCS and ATCLS, positive items in both scales were assigned with a numeric value ranging between (5) strongly agree, (4) agree, (3) undecided, (2) disagree, (1) strongly disagree, and negative items were assigned with their reversed. The maximum scores which a student could obtain from the ATCS and ATCLS were 125 and 135 respectively.

While analysing the pre and post test scores of both two tier diagnostic test and attitude scales, firstly, Shapiro Wilk test was used to identify whether the data was normally distributed or not. According to the results, Mann Whitney U test and Wilcoxon Signed Ranks Test were conducted to compare pre-test mean scores and post- test mean scores of the pre-service elementary teachers in both groups.

\subsection{Procedure}

In this study, pre- and post- test design with control group was used. At the beginning of the study, TTCT, ATCS and ATCLS were applied to both groups. The same laboratory activities were conducted by using predictobserve-explain task in the experimental group and using a cook book traditional approach in the control group. After the instruction, TTCT, ATCS and ATCLS were applied.

\subsubsection{Instructions in the experimental group}

At the beginning of the study, the pre-service elementary teachers were informed about learning process. In this process, a brief orientation including group rules, student and instructor roles, and evaluation strategies in the POE process was held to prepare them for the laboratory activities. In the experimental group, 26 the pre-service elementary teachers were randomly stratified into six groups. Instruction was conducted with laboratory activities based on POE tasks. Ten POE tasks related to mixtures, physical and chemical changes, acids and bases, which are presented in Table 5, were developed, and worksheets were prepared for each task.

All of the POE tasks were started with a brief story about daily life. In the first stage, participants were required to read the story clearly, to discuss and inquiry the reason of the problem given in the story and to make a prediction. After they had conducted laboratory works in their cooperative groups, they discussed the conflict between their prediction and observation. The POE tasks were conducted during ten weeks in the experimental group in laboratory setting. All the laboratory activities were done by the pre-service elementary teachers in cooperative groups under the guidance of the instructor. An example worksheet for POE task is given in Figure 1.

In the first step of this task, an antacid was given to the pre-service elementary teachers. They were required to read the prospectus and to predict how the antacid affects heartburn in the stomach. Then, they justified their prediction and wrote their prediction on the worksheet. In the second step, they carried out the laboratory activity by using $0.1 \mathrm{M} \mathrm{HCl}$ solution, antacid for stomach and $\mathrm{pH}$ paper. They were steered to write their observations. In the last step, they were asked to amend and add their explanation to take account of the observation and to reconcile any conflict between their prediction and observation. During the POE tasks, the instructor encouraged the pre-service elementary teachers to discuss and share their knowledge with their peers in the groups. Finally, they shared their explanation with their classmates. 
Table 5. POE task used in this study

\begin{tabular}{|c|c|c|c|c|}
\hline POE Tasks & Purpose & Predict & Observe & Explain \\
\hline $\begin{array}{l}\text { While it is } \\
\text { mixing, it is } \\
\text { complica- } \\
\text { ting }\end{array}$ & $\begin{array}{l}\text { Students will be able } \\
\text { to learn dissolution } \\
\text { concept, homo- } \\
\text { heterogeneous solu- } \\
\text { tions, and classifica- } \\
\text { tion of solution types. }\end{array}$ & $\begin{array}{l}\text { Predict what will happen if } \\
\text { you add salt, olive oil, } \\
\text { paper clip, sand, match } \\
\text { and flour to a cup of water. } \\
\text { Discuss in your group and } \\
\text { write down your predic- } \\
\text { tion. State and explain the } \\
\text { reasons of your prediction. }\end{array}$ & $\begin{array}{l}\text { Carry out hands-on } \\
\text { activity by using } \\
\text { mentioned material } \\
\text { and write down } \\
\text { your observation. }\end{array}$ & $\begin{array}{l}\text { Compare your pre- } \\
\text { diction and observa- } \\
\text { tion. Are they in } \\
\text { agreement or disa- } \\
\text { greement? Discuss in } \\
\text { your group and } \\
\text { explain your reasons. }\end{array}$ \\
\hline Lemonade & $\begin{array}{l}\text { Students will be able } \\
\text { to learn effects of } \\
\text { stirring and heating } \\
\text { on solubility }\end{array}$ & $\begin{array}{l}\text { Predict how the sugar at } \\
\text { the bottom of the beaker } \\
\text { could be decomposed in } \\
\text { the given scenario related } \\
\text { to making lemonade. } \\
\text { Discuss in your group and } \\
\text { write down your predic- } \\
\text { tion. State and explain the } \\
\text { reasons of your prediction. }\end{array}$ & $\begin{array}{l}\text { Carry out hands-on } \\
\text { activity by using } \\
\text { mentioned material } \\
\text { and write down } \\
\text { your observation. }\end{array}$ & $\begin{array}{l}\text { Compare your pre- } \\
\text { diction and observa- } \\
\text { tion. Are they in } \\
\text { agreement or disa- } \\
\text { greement? Discuss in } \\
\text { your group and } \\
\text { explain your reasons. }\end{array}$ \\
\hline $\begin{array}{l}\text { What } \\
\text { happen to } \\
\text { soft drink }\end{array}$ & $\begin{array}{l}\text { Students will be able } \\
\text { to learn factors effect- } \\
\text { ing solubility of gases }\end{array}$ & $\begin{array}{l}\text { Predict what will happen if } \\
\text { you open a crown cap } \\
\text { including soft drink after } \\
\text { you shaken or put near } \\
\text { stove. Discuss in your } \\
\text { group and write down } \\
\text { your prediction. State and } \\
\text { explain the reasons of your } \\
\text { prediction. }\end{array}$ & $\begin{array}{l}\text { Carry out hands-on } \\
\text { activity by using } \\
\text { mentioned material } \\
\text { and write down } \\
\text { your observation. }\end{array}$ & $\begin{array}{l}\text { Compare your pre- } \\
\text { diction and observa- } \\
\text { tion. Are they in } \\
\text { agreement or disa- } \\
\text { greement? Discuss in } \\
\text { your group and } \\
\text { explain your reasons. }\end{array}$ \\
\hline $\begin{array}{l}\text { Let's } \\
\text { produce } \\
\text { electric }\end{array}$ & $\begin{array}{l}\text { Students will be able } \\
\text { to learn electrolyte } \\
\text { and nonelectrolyte } \\
\text { solutions' properties }\end{array}$ & $\begin{array}{l}\text { Predict what will happen } \\
\text { conducting wire with lamb } \\
\text { is immersed to salt solu- } \\
\text { tion and sugar solution. } \\
\text { Discuss in your group and } \\
\text { write down your predic- } \\
\text { tion. State and explain the } \\
\text { reasons of your prediction. }\end{array}$ & $\begin{array}{l}\text { Carry out hands-on } \\
\text { activity by using } \\
\text { battery, conducting } \\
\text { wire with lamb, salt } \\
\text { solution and sugar } \\
\text { solution and write } \\
\text { down your observa- } \\
\text { tion. }\end{array}$ & $\begin{array}{l}\text { Compare your pre- } \\
\text { diction and observa- } \\
\text { tion. Are they in } \\
\text { agreement or disa- } \\
\text { greement? Discuss in } \\
\text { your group and } \\
\text { explain your reasons. }\end{array}$ \\
\hline $\begin{array}{l}\text { Journey of } \\
\text { Matters }\end{array}$ & $\begin{array}{l}\text { Students will be able } \\
\text { to learn physical and } \\
\text { chemical changes } \\
\text { some matter. }\end{array}$ & $\begin{array}{l}\text { Predict what will happen } \\
\text { sugar in the beaker and ice } \\
\text { in the beaker are heated. } \\
\text { Discuss in your group and } \\
\text { write down your predic- } \\
\text { tion. State and explain the } \\
\text { reasons of your prediction. }\end{array}$ & $\begin{array}{l}\text { Carry out hands-on } \\
\text { activity by ice, sugar, } \\
\text { two same beakers, a } \\
\text { heater and write } \\
\text { down their observa- } \\
\text { tion. }\end{array}$ & $\begin{array}{l}\text { Compare your pre- } \\
\text { diction and observa- } \\
\text { tion. Are they in } \\
\text { agreement or disa- } \\
\text { greement? Discuss in } \\
\text { your group and } \\
\text { explain your reasons. }\end{array}$ \\
\hline $\begin{array}{l}\text { Chemicals } \\
\text { around us I }\end{array}$ & $\begin{array}{l}\text { Students will be able } \\
\text { to learn how some } \\
\text { material in daily life } \\
\text { effect litmus paper } \\
\text { and its being classi- }\end{array}$ & $\begin{array}{l}\text { Predict which material is } \\
\text { acid and which one is base } \\
\text { and then classify the mate- } \\
\text { rial as acid or base which } \\
\text { was given to you. Discuss }\end{array}$ & $\begin{array}{l}\text { Carry out } \\
\text { hands-on activity } \\
\text { with lemon, soft } \\
\text { drink, milk, dish } \\
\text { soap, muruatic acid, }\end{array}$ & $\begin{array}{l}\text { Compare your pre- } \\
\text { diction and observa- } \\
\text { tion. Are they in } \\
\text { agreement or disa- } \\
\text { greement? Discuss in }\end{array}$ \\
\hline
\end{tabular}




\begin{tabular}{|c|c|c|c|c|}
\hline & $\begin{array}{l}\text { fied this material as } \\
\text { acid or base. }\end{array}$ & $\begin{array}{l}\text { in your group and write } \\
\text { down your prediction. } \\
\text { State and explain the } \\
\text { reasons of your prediction }\end{array}$ & $\begin{array}{l}\text { water, vinegar, drain } \\
\text { opener and write } \\
\text { down your observa- } \\
\text { tion. }\end{array}$ & $\begin{array}{l}\text { your group and } \\
\text { explain your reasons. }\end{array}$ \\
\hline $\begin{array}{l}\text { Chemicals } \\
\text { around us II }\end{array}$ & $\begin{array}{l}\text { Students will be able } \\
\text { to learn the effects of } \\
\text { acids and bases to } \\
\text { different indicators. }\end{array}$ & $\begin{array}{l}\text { Predict what changes will } \\
\text { the acid and base solu- } \\
\text { tion's colour add to this } \\
\text { different indicator. Discuss } \\
\text { in your group and write } \\
\text { down your prediction. } \\
\text { State and explain the } \\
\text { reasons of your prediction. }\end{array}$ & $\begin{array}{l}\text { Carry out hands-on } \\
\text { activity by using } \\
\text { same materials in } \\
\text { Task- } 6 \text { and tea, red } \\
\text { cabbage juice, } \\
\text { bromcresol green } \\
\text { and write down } \\
\text { your observation. }\end{array}$ & $\begin{array}{l}\text { Compare your pre- } \\
\text { diction and observa- } \\
\text { tion. Are they in } \\
\text { agreement or disa- } \\
\text { greement? Discuss in } \\
\text { your group and } \\
\text { explain your reasons. }\end{array}$ \\
\hline $\begin{array}{l}\text { Chemicals } \\
\text { around us } \\
\text { III }\end{array}$ & $\begin{array}{l}\text { Students will be able } \\
\text { to learn how different } \\
\text { concentration of acids } \\
\text { and bases affect on } \\
\text { indicators. }\end{array}$ & $\begin{array}{l}\text { Predict how different } \\
\text { concentration of acids and } \\
\text { bases affect indicators. } \\
\text { Discuss in your group and } \\
\text { write down your predic- } \\
\text { tion. State and explain the } \\
\text { reasons of your prediction. }\end{array}$ & $\begin{array}{l}\text { Carry out hands-on } \\
\text { activity by using } \\
\text { strength acid and } \\
\text { strength base, } \\
\text { bromcresol green } \\
\text { indicator and write } \\
\text { down your observa- } \\
\text { tion }\end{array}$ & $\begin{array}{l}\text { Compare your pre- } \\
\text { diction and observa- } \\
\text { tion. Are they in } \\
\text { agreement or disa- } \\
\text { greement? Discuss in } \\
\text { your group and } \\
\text { explain your reasons. }\end{array}$ \\
\hline Heartburn & $\begin{array}{l}\text { Students will be able } \\
\text { to learn neutralization } \\
\text { and how different } \\
\text { concentration of acid } \\
\text { and base effect neu- } \\
\text { tralization and } \mathrm{pH} \text { of } \\
\text { a solution. }\end{array}$ & $\begin{array}{l}\text { Read the prospectus of } \\
\text { medicine for stomach and } \\
\text { predict how the medicine } \\
\text { affects heartburn in the } \\
\text { stomach. Discuss in your } \\
\text { group and write down } \\
\text { your prediction. State and } \\
\text { explain the reasons of your } \\
\text { prediction. }\end{array}$ & $\begin{array}{l}\text { Carry out hands-on } \\
\text { activity by } 0.1 \mathrm{M} \\
\mathrm{HCl} \text { solution, medi- } \\
\text { cine for stomach and } \\
\mathrm{pH} \text { paper and write } \\
\text { down your observa- } \\
\text { tion. }\end{array}$ & $\begin{array}{l}\text { Compare your pre- } \\
\text { diction and observa- } \\
\text { tion. Are they in } \\
\text { agreement or disa- } \\
\text { greement? Discuss in } \\
\text { your group and } \\
\text { explain your reasons. }\end{array}$ \\
\hline $\begin{array}{l}\text { How much } \\
\text { does your } \\
\text { necklace } \\
\text { rost? }\end{array}$ & $\begin{array}{l}\text { Students will be able } \\
\text { to learn effect of acids } \\
\text { to metals }\end{array}$ & $\begin{array}{l}\text { Predict what will happen } \\
\text { to metal material put into } \\
\text { concentrated acid in the } \\
\text { baker. Discuss in your } \\
\text { group and write down } \\
\text { your prediction. State and } \\
\text { explain the reasons of your } \\
\text { prediction. }\end{array}$ & $\begin{array}{l}\text { Carry out hands-on } \\
\text { activity by beaker, } \\
\text { concentrated acid, } \\
\text { different metal } \\
\text { sample and write } \\
\text { down your observa- } \\
\text { tion. }\end{array}$ & $\begin{array}{l}\text { Compare your pre- } \\
\text { diction and observa- } \\
\text { tion. Are they in } \\
\text { agreement or disa- } \\
\text { greement? Discuss in } \\
\text { your group and } \\
\text { explain your reasons. }\end{array}$ \\
\hline
\end{tabular}




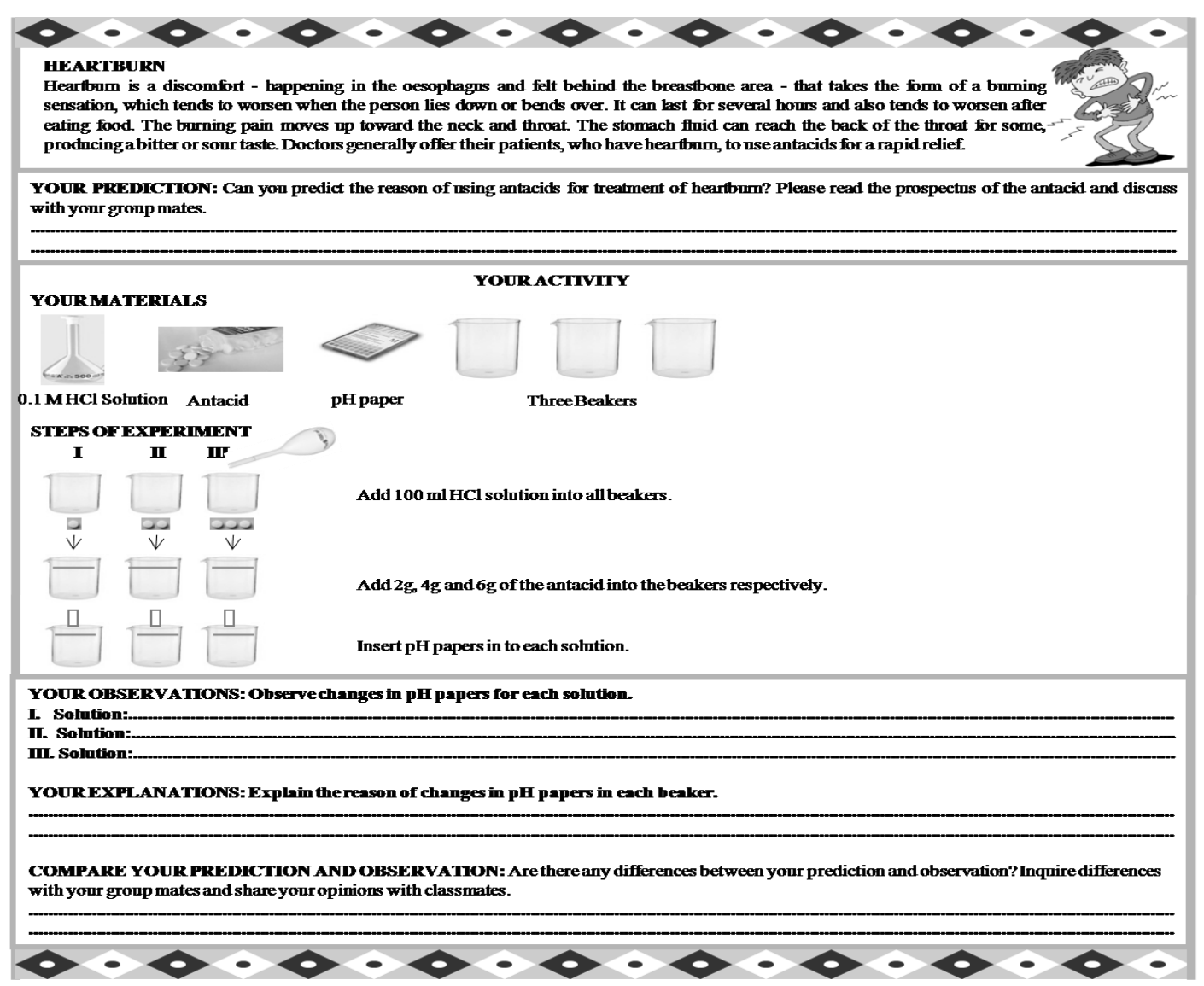

Figure 1. An example worksheet based on POE task

\subsubsection{Instructions in the control group}

In the control group, same laboratory activities were conducted in traditional cook-book laboratory settings. The pre-service elementary teachers followed the experimental procedure and directions in the worksheets. During this process, they were required to write the purpose of the activity, conduct laboratory activities, record their observations and discuss their results. An example worksheet used in the control group is given in the Figure 2 . 


\section{NEUTRALIZATION OF ACID AND BASE}

Purpose:

Materials:

0,1 $\mathrm{M} \mathrm{HCl}$ solution, antiacid, 3 beakers, $\mathrm{pH}$ paper.

\section{Procedure:}

1. Add $100 \mathrm{ml} \mathrm{HCl}$ solution into all beakers.

2. Add $2 \mathrm{~g}, 4 \mathrm{~g}$ and $6 \mathrm{~g}$ of the antacid into the beakers respectively.

3. Investigate the changes of $\mathrm{pH}$ using $\mathrm{pH}$ paper.

Observations:

Results and Discussion:

Figure 2. An example worksheet based on traditional approach.

\section{RESULTS}

\subsection{Results of Shapiro Wilk Test}

Firstly, Shapiro Wilk test was used to identify

Table 6. Shapiro Wilk test results of the pre-test and post-test

\begin{tabular}{llllll}
\hline & & Group & Statistic & df & $p$ \\
\hline TTCT & Pre-test & Experimental & 0.950 & 26 & 0.309 \\
& & Control & 0.930 & 30 & 0.062 \\
& Post-test & Experimental & 0.886 & 26 & $0.010^{*}$ \\
& & Control & 0.845 & 30 & $0.010^{*}$ \\
ATCS & Pre-test & Experimental & 0.957 & 26 & 0.395 \\
& & Control & 0.926 & 30 & 0.048 \\
& Post-test & Experimental & 0.967 & 26 & 0.554 \\
& & Control & 0.941 & 30 & 0.124 \\
& Pre-test & Experimental & 0.686 & 26 & $0.010^{*}$ \\
& & Control & 0.873 & 30 & $0.010^{*}$ \\
& Post-test & Experimental & 0.923 & 26 & 0.060 \\
& & Control & 0.818 & 30 & $0.010^{*}$ \\
\hline
\end{tabular}

The results showed that there was not a normal distribution for the all of the pre-test and posttest scores for both groups. For this reason, whether the pre-test and post-test scores were normally distributed or not (Table 6). 
Descriptive statistics of the pre-TTCT and post-

TTCT were presented in Table 7.

Table 7. Descriptive statistics of the pre- and post-TTCT

\begin{tabular}{cccccc}
\hline Group & Test & Mean & Standart Deviation & Minimum Score & Maximum Score \\
\hline Experimental & Pre-test & 8.15 & 2.89 & 4.00 & 15.00 \\
& Post-test & 14.92 & 4.44 & 8.00 & 21.00 \\
Control & Pre-test & 8.13 & 2.21 & 5.00 & 14.00 \\
& Post-test & 9.93 & 1.91 & 5.00 & 12.00 \\
\hline
\end{tabular}

Results showed that the pre-test and post-test mean scores of the experimental group were 8.15 and 14.92, and 8.13 and 9.93 for the control group respectively.
Mann Whitney U test was used for comparing the pre-test scores and the post-test scores of the groups before and after the instruction (Table 8).

Table 8. Mann Whitney U Test results of the pre-test and post-test TTCT

\begin{tabular}{|c|c|c|c|c|c|c|}
\hline & Group & $\mathrm{N}$ & Mean Rank & Sum of Rank & $\mathrm{U}$ & $\mathrm{p}$ \\
\hline \multirow[t]{2}{*}{ Pre-test } & Experimental & 26 & 28.17 & 732.50 & 381.500 & 0.888 \\
\hline & Control & 30 & 28.78 & 863.50 & & \\
\hline \multirow[t]{2}{*}{ Post-test } & Experimental & 26 & 37.83 & 983.50 & 147.500 & 0.000 \\
\hline & Control & 30 & 20.42 & 612.50 & & \\
\hline
\end{tabular}

According to results, while there was no statistically significant difference between the experimental and control groups ( $\mathrm{U}=381.500, \mathrm{p}>0.05)$, there was statistically significant difference between the experimental and control groups' post test scores in favour of the experimental group ( $\mathrm{U}=147.500, \mathrm{p}<0.05, \mathrm{z}=-4.018, \mathrm{r}=0.54)$.
Wilcoxon Signed Ranks test was used to compare the pre and post-test scores of the groups (Table 9). According to results, there was statistically significant difference between the pre and post-test scores of both experimental $(z=-$ 4.031, $\mathrm{p}<0.05, \mathrm{r}=0.56)$ and control groups $(\mathrm{z}=-$ 3.186, $\mathrm{p}<0.05, \mathrm{r}=0.41$ ) in favour of the post test score.

Table 9. Wilcoxon Signed Ranks test results of the pre-test and post test TTCT

\begin{tabular}{|c|c|c|c|c|c|c|}
\hline Grup & Post-Test-Pre-test & $\mathrm{N}$ & Mean Rank & Sum of Rank & $\mathrm{Z}$ & $\mathrm{p}$ \\
\hline \multirow{3}{*}{ Experimental } & Negative Ranks & 3 & 3.00 & 9.00 & $-4.031^{*}$ & 0.000 \\
\hline & Positive Ranks & 21 & 13.86 & 291.00 & & \\
\hline & Ties & 2 & & & & \\
\hline \multirow{3}{*}{ Control } & Negative Ranks & 5 & 10.20 & 51.00 & $-3.186^{*}$ & 0.000 \\
\hline & Positive Ranks & 21 & 14.29 & 300.00 & & \\
\hline & Ties & 4 & & & & \\
\hline
\end{tabular}

Note: *Based on negative ranks

The pre-service elementary teachers' responses to the two-tier concept test before and after the instruction were also analyzed to determine their conceptions. Totally 19 alternative concepts related to properties of acids and bases, acids and bases in the daily life, $\mathrm{pH}$, indicators, neutralization, solutions, solubility and factors effecting solubility, physical and chemical changes were determined in the pre-test. As it can be seen from Table 10, percentage of these alternative conceptions decreased after the instruction. 
Table 10. Percentages of alternative concepts determined in the pre test and post test

\begin{tabular}{|c|c|c|c|c|}
\hline \multirow[t]{2}{*}{ Pre-service elementary teachers Alternative Concepts } & \multicolumn{2}{|c|}{ Experimental Group } & \multicolumn{2}{|c|}{ Control Group } \\
\hline & $\begin{array}{c}\text { Pre Test } \\
(\%)\end{array}$ & $\begin{array}{l}\text { Post } \\
\text { Test } \\
(\%)\end{array}$ & $\begin{array}{c}\text { Pre } \\
\text { Test } \\
(\%)\end{array}$ & $\begin{array}{l}\text { Post } \\
\text { Test } \\
(\%)\end{array}$ \\
\hline If stirring rate increases, solubility increases. & 25 & 5 & 30 & 10 \\
\hline $\begin{array}{l}\text { Solution is a maximum amount of a solute that can be dis- } \\
\text { solved in a solvent. }\end{array}$ & 36 & 22 & 45 & 30 \\
\hline Solvent is always liquid. & 29 & 7 & 20 & 10 \\
\hline If sugar is added to water in a beaker, it melts. & 32 & 11 & 35 & 30 \\
\hline $\begin{array}{l}\text { If sugar is added to water in a beaker, sugar ions are sur- } \\
\text { rounded by water molecules. }\end{array}$ & 43 & 30 & 50 & 40 \\
\hline If salt dissolves in water it disappears. & 25 & 19 & 20 & 10 \\
\hline $\begin{array}{l}\text { If a solute is added to a saturated solution, the solution be- } \\
\text { comes supersaturated. }\end{array}$ & 50 & 19 & 40 & 30 \\
\hline $\begin{array}{l}\text { If silver tarnished, physical change occurs owing the fact } \\
\text { that the physical appearance has changed. }\end{array}$ & 21 & 4 & 25 & 22 \\
\hline $\begin{array}{l}\text { If a test tube including iron and sulphur is heated, physical } \\
\text { change occurs. }\end{array}$ & 46 & 37 & 50 & 45 \\
\hline $\begin{array}{l}\text { When a test tube including iron and sulphur is heated, iron } \\
\text { and sulphur melt. }\end{array}$ & 21 & 4 & 22 & 20 \\
\hline All acids are poisonous. & 43 & 22 & 30 & 15 \\
\hline $\begin{array}{l}\text { Acids always turn indicators to red colour, bases turn them } \\
\text { to blue colour }\end{array}$ & 71 & 48 & 80 & 60 \\
\hline Acids melt everything. & 43 & 26 & 50 & 40 \\
\hline $\mathrm{pH}$ is the measure of acid strength. & 64 & 33 & 68 & 40 \\
\hline $\begin{array}{l}\text { If acid and bases are not at the same amount, neutralization } \\
\text { does not occur. }\end{array}$ & 21 & 15 & 25 & 20 \\
\hline Water and salt are always formed after acid-base reactions. & 32 & 15 & 30 & 25 \\
\hline $\begin{array}{l}\text { Neutral solutions are always formed in all neutralization } \\
\text { reactions. }\end{array}$ & 40 & 19 & 25 & 10 \\
\hline $\begin{array}{l}\text { Because acids burn everything, they can give combustion } \\
\text { reactions. }\end{array}$ & 43 & 33 & 30 & 15 \\
\hline $\begin{array}{l}\text { Carbon and oxygen gases react with water and they neutral- } \\
\text { ize during combustion reaction. }\end{array}$ & 29 & 19 & 25 & 15 \\
\hline
\end{tabular}

\subsection{Results of Attitude toward Chemistry}

\section{Lesson Scale}

Descriptive statistics of the pre-test and posttest ATCS were presented in Table 11. The results showed that the pre-test and post-test mean scores of experimental group were 76.65 and 89.85 , and the pre-test and post-test mean scores of control group were 75.63 and 76.13 respectively. 
Table 11. Descriptive statistics of the pre-test and post-test ATCS

\begin{tabular}{llcccc}
\hline Group & Test & Mean & Standart Deviation & Minimum Score & Maximum Score \\
\hline Experimental & Pre-test & 76.65 & 18.26 & 49.00 & 115.00 \\
& Post-test & 89.85 & 9.71 & 75.00 & 115.00 \\
Control & Pre-test & 75.63 & 12.28 & 55.00 & 99.00 \\
& Post-test & 76.13 & 8.45 & 57.00 & 100.00 \\
\hline
\end{tabular}

Mann Whitney U test was used for comparing before and after the instruction (Table 12). the pre-test and post test scores of the groups

Table 12. Mann Whitney $U$ test results of the pre-test and post-test ATCS

\begin{tabular}{lllcccc}
\hline & Group & $\mathrm{N}$ & Mean Rank & Sum of Rank & $\mathrm{U}$ & $\mathrm{p}$ \\
\hline \multirow{2}{*}{ Pre-test } & Experimental & 26 & 29.21 & 759.50 & 371.500 & 0.761 \\
& Control & 30 & 27.88 & 836.50 & & \\
\hline \multirow{2}{*}{ Post-test } & Experimental & 26 & 39.46 & 1026.00 & 105.000 & 0.000 \\
& Control & 30 & 19.00 & 570.00 & & \\
\hline
\end{tabular}

Based on the results, while there was no statistically significant difference between the experimental and control groups ( $\mathrm{U}=371.500, \mathrm{p}>0.05)$, there was statistically significant difference between the experimental and control groups' post test score in favour of the experimental group $(\mathrm{U}=105.000, \mathrm{p}<0.05, \mathrm{z}=-4.690, \mathrm{r}=0.63)$.

Wilcoxon Signed Ranks test was used to compare the pre and post-test scores of the groups (Table 13). Based on the results, while there was statistically significant difference between the pre and post-test scores of the experimental group $(\mathrm{z}=-2.604, \mathrm{p}<0.05, \mathrm{r}=0.36)$ in favour of the post test score, there was no statistically significant difference between the pre and post-test score of the control groups $(z=-$ $0.319, \mathrm{p}>0.05)$.

Table 13. Wilcoxon Signed Ranks test results of the pre-test and post test ATCS

\begin{tabular}{llccccc}
\hline Grup & Post-Test-Pre-test & $\mathrm{N}$ & $\begin{array}{c}\text { Mean } \\
\text { Rank }\end{array}$ & $\begin{array}{c}\text { Sum of } \\
\text { Rank }\end{array}$ & $\mathrm{Z}$ & $\mathrm{p}$ \\
\hline \multirow{4}{*}{ Experimental } & Negative Ranks & 8 & 9.13 & 73.00 & $-2.604^{*}$ & 0.009 \\
& Positive Ranks & 18 & 15.44 & 278.00 & & \\
& Ties & 0 & & & & \\
\hline \multirow{5}{*}{ Control } & Negative Ranks & 15 & 14.47 & 217.00 & $-0.319^{*}$ & 0.750 \\
& Positive Ranks & 15 & 16.53 & 248.00 & & \\
\hline
\end{tabular}

Note: *Based on negative ranks

\subsection{Results of Attitude toward Chemistry Laboratory Scale}

Descriptive statistics of the pre-test and posttest ATCLS were presented in Table 14. The results showed that the pre-test and post-test mean scores of experimental group were 99.50 and 109.15, and the pre-test and the post-test mean score of the control group were 98.90 and 100.77 respectively. 
Table 14. Descriptive statistics of the pre-test and post-test ATCLS

\begin{tabular}{llcccc}
\hline Group & Test & Mean & $\begin{array}{c}\text { Standart De- } \\
\text { viation }\end{array}$ & Minimum Score & Maximum Score \\
\hline Experimental & Pre-test & 99.50 & 12.54 & 47.00 & 112.00 \\
& Post-test & 109.15 & 8.02 & 96.00 & 123.00 \\
Control & Pre-test & 98.90 & 13.41 & 78.00 & 120.00 \\
& Post-test & 100.77 & 12.66 & 88.00 & 125.00 \\
\hline
\end{tabular}

Mann Whitney U test was used for comparing the pre-test and post test scores of the groups before and after the instruction (Table 15).

The results reflected that, while there was no statistically significant difference between the experimental and control groups $(\mathrm{U}=343.500$, $\mathrm{p}>0.05)$, there was statistically significant difference between the experimental and control groups' post test scores in favour of the experimental group $(U=201.500, p<0.05, \quad z=-3.106$, $\mathrm{r}=0.42)$.

Table 15. Mann Whitney $U$ test results of the pre-test and post-test ATCLS

\begin{tabular}{lllcccc}
\hline & Group & $\mathrm{N}$ & Mean Rank & Sum of Rank & $\mathrm{U}$ & $\mathrm{p}$ \\
\hline \multirow{2}{*}{ Pre-test } & Experimental & 26 & 30.29 & 787.50 & 343.500 & 0.444 \\
& Control & 30 & 26.95 & 808.50 & & \\
\hline \multirow{2}{*}{ Post-test } & Experimental & 26 & 35.75 & 929.50 & 201.500 & 0.002 \\
& Control & 30 & 22.22 & 666.50 & & \\
\hline
\end{tabular}

Wilcoxon Signed Ranks test was used to compare the pre and post-test scores of the groups (Table 16). According to the results, while there was statistically significant difference between the pre and post-test scores of experimental group $(\mathrm{z}=-2.999, \mathrm{p}<0.05, \mathrm{r}=0.42)$ in favour of the post test scores, there was no statistically significant difference between the pre and post-test score of control groups $(\mathrm{z}=-1.470, \mathrm{p}>0.05)$.

Table 16. Wilcoxon Signed Ranks test results of the pre-test and post test ATCLS

\begin{tabular}{llccccc}
\hline Grup & Post-Test-Pre-test & $\mathrm{N}$ & $\begin{array}{c}\text { Mean } \\
\text { Rank }\end{array}$ & $\begin{array}{c}\text { Sum of } \\
\text { Rank }\end{array}$ & $\mathrm{Z}$ & $\mathrm{p}$ \\
\hline \multirow{4}{*}{ Experimental } & Negative Ranks & 7 & 8.21 & 57.50 & -2.999 & 0.003 \\
& Positive Ranks & 19 & 15.45 & 293.50 & & \\
& Ties & 0 & & & & \\
\hline \multirow{5}{*}{ Control } & Negative Ranks & 6 & 23.08 & 138.50 & -1.470 & 0.142 \\
& Positive Ranks & 22 & 12.16 & 267.50 & & \\
\hline
\end{tabular}

Note: *Based on negative ranks

\section{DISCUSSION}

In this study, the effects of POE task on the preservice elementary teachers' understanding and their attitude toward chemistry lesson and chemistry laboratory were investigated. The results showed that laboratory activities based on POE task were more effective than the traditional cook-book laboratory setting for promoting the pre-service elementary teachers' conceptual understanding. According to the results 19 alternative concepts were determined in this study. For example, it was found that the preservice elementary teachers reflected alternative concepts related to solubility as; "If a solute 
is added to a saturated solution, the solution becomes supersaturated" and "Solution is a maximum amount of a solute that can be dissolved in a solvent". The same alternative concepts were also identified by Karamustafaoglu et al (2002). These alternative concepts underlined that the pre-service elementary teachers confused saturated solution with supersaturated solutions, and solution with solubility concepts. After the instruction, the percentages of these alternative concepts in the experimental group decreased more than the percentages in the control group as it can be seen in Table 10. This situation can be explained by the second POE Task in which the pre-service elementary teachers had an opportunity to discuss about these concepts. In addition to this, it was determined that they had an alternative concept "If sugar is added water in a beaker, it melts". This shows that the pre-service elementary teachers had difficulties in determining melting and dissolution as described by Calik and Ayas (2005), Pinarbasi et al. (2007), Tsaparlis (2003). Moreover, the pre-service elementary teachers had alternative concepts such as "If stirring rate increases, solubility increases". This situation revealed that they confused the effective factors on solubility rate and solubility. Also, before the instruction while the pre-service elementary teachers percentage of having alternative conceptions was $25 \%$ and $30 \%$ in the experimental group and control group respectively, this value decreased to $5 \%$ in the experimental group and to $\% 10$ in the control group after the instruction. In the context of the second POE task named as Lemonade, the pre-service elementary teachers in the experimental group predicted that some factors were effective on solubility rate, so they observed their prediction and discussed the effective factors on solubility rate and the differences of these factors from effective factors on solubility under the guidance of instructor. The pre-service elementary teachers in the control group only followed directions; therefore the POE task was more effective than the laboratory activities based on traditional cook- book laboratory setting in the control group for remedying this alternative concept.

Alternative concepts related to physical and chemical changes were also identified in this study. It was found that the percentages of these alternative concepts in the experimental group such as "When silver tarnished, physical change occurs owing to physical appearance changed", "When a test tube including iron and sulphur is heated, physical change occurs" were remedied better than the concepts in the control group after the instruction (Table 10). In the context of the fifth POE task named as Journey of Matter, the pre-service elementary teachers in the experimental group predicted what changes would occur in an experiment, so they conducted the experiment in which physical and chemical changes were created by using ice and sugar, and then they compared and discussed physical and chemical changes based on their observations and predictions. So they interpreted the new physical and chemical changes more easily than the control group and those alternative concepts were remedied better after the instruction.

According to the pre-service elementary teachers' answers, it is understood that they confused chemical and physical changes as it was identified by Ayvaci and Coruhlu (2009), Hesse and Anderson (1992). Moreover, before the instruction while $71 \%$ and $\% 80$ of the preservice elementary teachers in the experimental group and control group respectively thought that "acids always turn indicators to red colour, bases turn them to blue colour", this value decreased to $48 \%$ in the experimental group and to $\% 60$ in the control group after the instruction. POE tasks named as Chemical around Us I, II and III were related to acid-base reaction and using indicators, the results showed that the tasks represented more positive conceptual change. The reason of this alternative concept is generally associated with giving a sample which describes the effects of acids and bases on litmus paper in books. This causes a conceptual conflict. Similarly, Morgil et al. (2002) de- 
termined alternative concepts related to the indicator. As it can be seen in Table 10, the percentage of alternative concepts related to neutralization decreased, and this situation showed that the POE task named as Heartburn in which the pre-service elementary teachers conducted an experiment related to neutralization by using antacid and HCL was effective for remedying the alternative concepts related to neutralization too.

During the POE instruction, the pre-service elementary teachers discussed their predictions about the story in prediction stage. These stories were derived from in daily life. The problems in daily life are meaningful and interesting for students (Jonassen, 1997), in this way they have opportunity to associate their learning with these daily life experience. Also, daily life applications provide them ability to apply the new situations to the learned ones (Costu, Unal \& Ayas, 2007). In this study, the preservice elementary teachers studied about their daily life experiences during the instruction and this instruction might have promoted their understanding. Furthermore, the POE tasks allowed the pre-service elementary teachers to investigate scientific phenomena in small groups. They made prediction about scientific events by inquiring, they observed those events and then they compared their prediction and explanation based on their observations they had made during the instruction. They removed the cognitive conflict between their prediction and observation by doing explanations. So, the POE tasks provided conceptual understanding and learning in-depth for them. Moreover, group discussions gave the preservice elementary teachers opportunity to share different thoughts as it was declared by Costu, Ayas and Niaz (2010, 2012), White and Gunstone (1992). Additionally, in coherence with the results, the research similarly reported that POE activities promoted understanding of scientific concepts adequately (Akgun \& Deryakulu, 2007; Costu, Ayas \& Niaz, 2010, 2012; Kearney, 2004; Searle \& Gunstone, 1990; Tao \& Gunstone, 1997, 1999).
On the other hand, the results of ATCS showed that there was no significant difference between the control and experimental groups' pre- attitudes toward chemistry lesson before instruction. However, it was found that there was a statistically significant difference between the experimental and control groups' ATCS scores in favour of the experimental group after the instruction. These results showed that the laboratory activities, based on POE tasks, promote the pre-service elementary teachers' attitude toward chemistry lesson positively. Similarly Koseoglu, Tumay \& Kavak (2002) found that POE task improved the preservice elementary teachers' attitudes toward chemistry lesson. Yavuz \& Celik (2013) underlined that, the POE task on the subject of gases promoted undergraduates' attitudes toward chemistry in coherence with the results of this research. Furthermore, ATCLS was applied before and after instruction. While there was no significant difference between the control and experimental groups' pre-attitudes toward chemistry laboratory, it was found that there was significant difference between the experimental and control groups' post-attitudes in favour of the experimental group. According to the results, laboratory activities based on POE task promoted the pre-service elementary teachers' attitude toward chemistry laboratory.

POE inquires to interpret nature of scientific event, in this way POE contributes attitude toward laboratory as indicated by Bilen and Aydogdu (2010). In this study worksheets including POE tasks were prepared and each task began a brief story related to learning issue, so they had opportunity to observe the learning subjects in daily life and they worked out a problem related to their experiences by completing the POE task. This situation might have promoted their concentration and interests to their investigation, and it might have affected their attitudes positively toward chemistry lesson and chemistry laboratory. Many researchers have underlined that, if the preservice elementary teachers associate the science subjects with daily life and they use this 
associations for social and environmental problems, their attitudes are influenced positively (Hofstein \& Mamlok-Naaman, 2011; Ramsden, 1998) like our results. Furthermore, cooperative team work was conducted during the process. POE activities enhanced the cooperative team work and provided the students an opportunity to assume responsibility, to develop selfconfidence, and to work as a scientist using scientific methods. In addition to this, cooperative team work increased individual responsibility (Coppola \& Lawton, 1995). Moreover, the pre-service elementary teachers completed their POE tasks actively under guidance of the instructor. In previous researches indicated that, the pre-service teachers' attitude toward chemistry promotes when they participate in learning process actively (Ben-Zvi, Hofstein, Samuel \& Kempa, 1976; Okebukola, 1986), they are responsible for their own learning (Bilen, 2009) in coherence with this study. Also, the pre-service elementary teachers' peer interactions and cooperation may influence their attitudes when they discussed during in all POE steps. During the instruction, the pre-service elementary teachers shared and discussed their personal predictions about the story in the predict stage; their observations and experiences related to experiment in the observe stage; their results, reconciliations, conflicts, interpretations and solutions in the explain stage. As White and Gunstone (1992) emphasized discussion is very important part of the POE and it is very effective especially in the explain phase. In addition to discussions, they inquired the reason of the problem given in the story in the predict stage and conflict between their prediction and observation in the explain stage.

\section{CONCLUSION}

In conclusion, according to the results of the study, application of laboratory activities developed based on POE related to "Mixtures, Physical and Chemical Changes, Acids and Bases" had a great role for increasing the pre-service elementary teachers' understanding of scientific concepts and developing positive attitudes towards chemistry lesson and chemistry laboratory, in contrast to traditional cook-book laboratory instruction. For this reason, it can be suggested that laboratory activities based on active learning methods like POE should be developed, used and generalized in the preservice education curriculum and chemistry classes widely. Also, alternative conceptions which were determined in this research and laboratory activities which were developed by the researcher will be guide researchers and instructors. Furthermore, two-tier diagnostic test which was developed this research will make major contributions for future research and it will provide with opportunities to educators and teachers to assess pre-service teachers' alternative conceptions and understanding of the target concepts. Researchers can use this test as pre-test and post-test for evaluating of effect of different learning environments on students' achievement and conceptual understanding.

\section{References}

Abdullah, M., Mohamed, N., \& Ismail, Z. H. (2009). The effect of an individualized laboratory approach through microscale chemistry experimentation on students' understanding of chemistry concepts, motivation and attitudes. Chemistry Education Research and Practice, 10(1), 53-61.

Acar, B. (2008). An active learning application based on constructivism for the subject of acid and bases in high school chemistry lesson. PhD Dissertation, Dokuz Eylul University, Educational Science Institute.

Acar Sesen, B. (2013). Diagnosing pre-service science teachers' understanding of chemistry concepts by using computer-mediated predict-observe-explain tasks. Chemistry Education Research and Practice, 14(3), 239246. 
Acar Sesen, B., \& Tarhan, L. (2013). Inquiry-based laboratory activities in electrochemistry: High school students' achievements and attitudes. Research in Science Education, 43(1), 413-435.

Akgun, O. E., \& Deryakulu, D. (2007). The effects of refutational text and predict observe explain strategies on students' levels of cognitive conflict and conceptual change. Ankara University Journal of Faculty of Educational Sciences, 40(1), 17-40.

Ayvaci, H. S., \& Coruhlu, T. S. (2009). Effects of explanatory stories on elimination of students' misconceptions about physical and chemical change. Ondokuz Mayis University Journal of Education Faculty, 28, 93-104.

Ben-Zvi, R., Hofstein, A., Samuel, D., \& Kempa, R. F. (1976). The attitude of high school students towards the use of filmed experiments. Journal of Chemical Education, 53(9), 575.

Berberoglu, G., \& Calikoglu, G. (1992). The construction of a Turkish computer attitude scale. Studies in Educational Evaluation, 24, 841-845.

Bilen, K. (2009). The effects of a laboratory instruction designed based on the predict observation explain strategy on preservice teachers on conceptual achievement, science process skills, attitudes and views about the nature of science. Doctoral Dissertation, Gazi University.

Bilen, K., \& Aydogdu, M. (2010). Using the predict-observe-explain (POE) strategy to teach of concetps photosynthesis and respiration in plants. Mustafa Kemal University Journal of Social Sciences Institute, 7(14), 179-194.

Bilen, K., \& Kose, S. (2012). An effective strategy based on constructivism: Predict-observe-explain (POE) growth and development in plant. Pamukkale Universitesi Egitim Fakultesi Dergisi, 31(1), 123-136.

Bradley J. D. (2001). UNESCO/IUPAC-CTC Global Program in Microchemistry, Pure and Applied Chemistry, 73, 1215-1219.

Calik, M., \& Ayas, A. (2005). A cross-age study on the understanding of chemical solutions and their components. International Education Journal, 6(1), 30-41.

Carlo, D. I., \& Bodner, G. M. (2004). Students' perceptions of academic dishonesty in the chemistry classroom laboratory. Journal of Research in Science Teaching, 41, 47-64.

Coppola, B. P., \& Lawton, R. G. (1995). Who has the same substance that I have? A blue print for collaborative learning activities. Journal of Chemical Education, 72(12), 1120-1122.

Costu, B., Ayas, A., \& Niaz, M. (2010). Promoting conceptual change in first year students' understanding of evaporation. Chemical Education Research and Practice, 11, 5-16.

Costu, B., Ayas, A., \& Niaz, M. (2012). Investigating the effectiveness of a POE-based teaching activity on students' understanding of condensation. Instructional Science, 40(1), 47-67.

Costu, B., Unal, S., \& Ayas, A. (2007). The use of daily-life events in science teaching. Ahi Evran Universitesi Kirsehir Egitim Fakultesi Dergisi, 8(1), 197-207.

Freedman, M. P. (1997). Relationships among laboratory instruction, attitudes toward science and achievement in science knowledge. Journal of Research in Science Teaching, 34, 343-357.

Green, S. B., \& Salkind, N. J. 2005. Using SPSS for Windows and Macintosh: Analyzing and Understanding Data. New Jersey: Prentice Hall Press.

Hesse, J. J., \& Anderson, C. W. (1992). Students' conceptions of chemical change. Journal of Research in Science Teaching, 29, 277-299.

Hofstein, A., \& Lunetta, V. N. (1982). The role of the laboratory in science teaching: Neglected aspects of research. Review of Educational Research, 52(2), 201-217. 
Hofstein, A., \& Lunetta, V. N. (2004). The laboratory in science education: foundations for the twenty-first century. Science Education, 88, 28-54.

Hofstein, A., \& Mamlok-Naaman, R. (2011). High-school students' attitudes toward and interest in learning chemistry. Educación química, 22, 90-102.

Hsu, L. R. (2004). Using the predict-observe-explain strategy to explore students' alternative conceptions of combustibility. Paper presented at the Annual Meeting of the National Association for Research in Science Teaching, Vancouver.

Johnstone, A. H., \& Wham, A. J. B. (1982). The demands of practical work. Education in Chemistry, 71-73.

Jonassen, D. H. (1997). Instructional design model forwell-structured and ill structured problem-solving learning outcomes. Educational Technology: Research and Development, 45(1), 45-94.

Karamustafaoglu, S., Ayas, A., \& Costu, B. (2002). Pre-service primary school teachers' misconceptions about solution and remedying these misconceptions by concept maps. Paper presented at Meeting of V. National Science and Mathematics Education, Ankara, Turkey.

Kearney, M. (2004). Classroom use of multimedia-supported predict-observe-explain tasks in a social constructivist learning environment. Research in Science Education, 34, 427-453.

Koballa, T. R. Jr. (1988). Attitude and related concepts in science education. Science Education, 72, 115- 126.

Koballa, T. R. Jr., Crawley, F. E., \& Shrigley, R. L. (1990). A summary of science education-1988. Science Education, 74, 369-381.

Kose, S., Costu, B., \& Keser O. F. (2003). Determination of students' misconceptions in science: activities through POE method. Pamukkale University Journal of Education Faculty, 13(1), 43-53.

Koseoglu, F., Tumay, H., \& Kavak, N. (2002). An effective teaching method based on constructivism predict observe explain, can be water boiled with ice. Paper presented at Meeting of V. National Science and Mathematics Education, Ankara, Turkey.

Krause, S., \& Tasooji, A. (2007). Diagnosing students' misconceptions on solubility and saturation for understanding of phase diagrams. ASEE Annual Conference Proceedings.

Liew, C. W., \& Treagust, D. F. (1998). The effectiveness of predict-observe-explain tasks in diagnosing students' understanding of science and in identifying their levels of achievement. Paper presented at the annual meeting of the American Educational Research Association, San Diego.

Lindahl, B. (2003). Changing the subject to get more students to science and technology. Paper presented at the GAST 11 conference, Mauritius.

Milner, N., Ben-Zvi, R., \& Hofstein, A. (1987). Variables that affect students' enrollment in science courses. Research in Science and Technological Education, 5, 201-208.

Morgil, I., Yilmaz, A., Sen, O., \& Yavuz, S. (2002). Students' misconceptions about acid-base and using different matters to identify misconceptions. Retrived from http://www.fedu.metu.edu.tr/ufbmek5/b_kitabi/PDF/Kimya/Bildiri/ t175DD.pdf 20.07.2011

Okebukola, P. A. (1986). Cooperative learning and students' attitudes to laboratory work. School Science and Mathematics, 86, 582-590.

Ramsden, P. (1998). Managing the effective university. Higher Education Research \& Development, 17(3), 347-370.

Roth, W. M. (1994). Experimenting in a constructivist high school physics laboratory. Journal of Research in Science Teaching, 31, 197-223. 
Salta, K., \& Tzougraki, C. (2004). Attitudes toward chemistry among 11th grade students in high schools in Greece. Science Education, 88(4), 535-547.

Schmidt, H. (1991). A label as a hidden persuader: chemists' neutralization concept. International Journal of Science Education, 13(4), 459-471

Searle, P., \& Gunstone, R. (1990). Conceptual change and physics instruction: A longitudinal study. ERIC Document, ED 320767.

Sheppard, K. (2006). High school students' understanding of titrations and related acid-base phenomena. Chemistry Education Research and Practice, 7(1), 32-45.

Singer, S. R., Hilton, M. L., \& Schweingruber, H. A. (Eds.) (2006). America's laboratory report: Investigations in high school science. Washington, DC: National Research Council.

Tao, P., \& Gunstone, R. (1997). The process of conceptual change in 'Force and Motion', ERIC Document, ED 407 259.

Tao, P., \& Gunstone, R. (1999). The process of conceptual change in force and motion during computersupported physics instruction. Journal of Research in Science Teaching, 36(7), 859-882.

Tarhan, L. (2008). Development of a material supported with active learning methods based on constructivism to prevent formation and remediation of misconceptions in the subject of acids and bases in the level of high school and university. Project supported by The Scientific and Technological Research Council of Turkey (TUBITAK) (Project number: TUB-105K058).

Thompson, J., \& Soyibo, K. (2002). Effects of lecture, teacher demonstrations, discussion and Practical work on $10^{\text {th }}$ graders' attitudes to chemistry and understanding of electrolysis. Research in Science $\mathcal{E}$ Technological Education, 20(1), 25-37.

Toplis, R. (1998). Ideas about acids and alkalis. School Science Review, 80(291), 67-70.

Treagust, D.F. (1988). Development and use of diagnostic tests to evaluate students misconceptions in science. International Journal of Science Education, 10(2), 159-169.

Tsaparlis, G. (2003). Basic chemical concepts. Chemistry Education Research and Practice, 4(1), 31-43.

Tsui, C. Y., \& Treagust, D. 2010. Evaluating Secondary Students' Scientific Reasoning in Genetics Using a TwoTier Diagnostic Instrument. International Journal of Science Education, 32(8), 1073-1098.

White, R. (1988). Learning science. Oxford, UK: Basil Blackwell.

White, R. T., \& Gunstone, R. F. (1992). Probing understanding. London: The Falmer Press.

Yavuz, S., \& Celik, G. (2013). The effect of predict-observe-explain (POE) technique on the misconceptions of prospective elementary teachers about the gases. Karaelmas Egitim Bilimleri Dergisi, 1(1), 1-20. 


\section{Genişletilmiş Özet}

Laboratuvar uygulamaları kimya eğitiminin vazgeçilmez bir parçasıdır ve bu ortamda öğrenciler işbirlikli çalışma, bilimsel prensip ve teorileri gerçek ortamda gözlemleme fırsatı bulurlar. Laboratuvar uygulamalarının pek çok olumlu etkisi olmasına karşın, geleneksel laboratuvar uygulamaları yönergelerin adım adım takip edilmesi sonucu daha az düşünmeye sevk etmesi, zamanla deneyin amacından uzaklaşılması, deneyin amacının anlaşılmaksızın sadece adımlarının takip edilmesi gibi bazı sınırlılıklara sahiptir. Bu sebeple laboratuvar uygulamalarının tahmin-gözlem-açıklama gibi aktif öğrenme yöntem ve teknikleri ile desteklenmesi büyük önem arz etmektedir.

Sunulan çalı̧̧mada "Karışımlar, Fiziksel ve Kimyasal Değişim, Asitler ve Bazlar" konularında tahmin gözlem açıklamaya dayalı laboratuvar etkinliklerinin sınıf öğretmeni adaylarının anlamalarına, kimya dersine ve kimya laboratuvarına karşı tutumlarına etkisinin incelenmesi amaçlanmıştır. Bu amaçla on laboratuvar etkinliği geliştirilmiştir. 56 sınıf öğretmeni adayının katılımıyla gerçekleşen çalışmada ilk olarak sınıf öğretmeni adayları deney $(\mathrm{N}=26)$ ve kontrol $(\mathrm{N}=30)$ gruplarına ayrılmıştır. Geliştirilen laboratuvar etkinlikleri deney grubunda kullanılmak üzere tahmin gözlem açıklama yaklaşımının basamakları temel alınarak çalışma kâğıdına dönüştürülmüştür. Çalı̧̧ma kâğıtlarında öğretmen adaylarının tahmin, gözlem ve açıklamalarını not alacakları uygun boşlukların bırakılmasına özen gösterilmiştir. Tüm etkinlikler kısa günlük hayat hikâyesi ile başlamıştır. İlk aşamada katılımcılardan bu hikâyeyi okumaları, hikâyede verilen problem durumunu sorgulamaları ve bir tahminde bulunmaları istenmiştir. Ardından öğretmen adayları tahminlerine ilişkin deney yapmış ve gözlemlerini kaydetmişlerdir. Son olarak tahminleri ile gözlemlerinin uyum sağlayıp sağlamadığını tartısmışlar, sonuçlarını paylaşmışlar ve etkinliği tamamlamışlardır. Tüm etkinlikler işbirlikli gruplar şeklinde öğretim üyesinin rehberliği altında gerçekleştirilmiştir. Aynı laboratuvar etkinlikleri kontrol grubu geleneksel yaklaşıma dayalı olarak hazırlanan deney yönergesine bağlı olarak yürütülmüştür.

Öğretmen adaylarının uygulamadan önce ve sonra olmak üzere akademik başarı düzeyini ve kavramsal anlamalarını belirlemek amacıyla araştırmacılar tarafından geliştirilen ve 23 maddeden oluşan İki Aşamalı Kavram Testi $(\alpha=0.72)$ kullanılmıştır. Öğretmen adaylarının kimya dersine ve kimya laboratuvarına karşı tutumlarını belirlemek amacıyla uygulamadan önce ve sonra olmak üzere Kimya Dersine Karşı Tutum Ölçeği ve Kimya Laboratuvarına Karşı Tutum Ölçeği kullanılmıştır.

İki aşamalı testin analizinde, toplam puan hesaplanırken eğer iki aşama doğru yanıtlanmışsa 1 puan, herhangi bir aşama yanlış yanıtlanmış ya da boş bırakılmışsa 0 puan verilmiştir. Bu yolla anlamlı öğrenmenin ölçülmesi ve şans başarısının azaltılması amaçlanmıştır. İki aşamalı diagnostik testin maddelerinin bir seçeneği doğru yanıt iken diğer seçenekler alternatif kavramları içerecek şekilde hazırlanmıştır. Bu sebeple kavramsal anlamanın değerlendirilmesinde testin maddelerine verilen her yanıt tek tek incelenmiş, maddelere ait seçeneklerin işaretlenme yüzdeleri hesaplanmıştır. \%20'den yüksek işaretlenme yüzdesine sahip olan alternatif kavramlar sonuç kısmında raporlaştırılmıştır. Kimya Dersine Karşı Tutum Ölçeği ve Kimya Laboratuvarına Karşı Tutum Ölçeği'nin değerlendirilmesinde her bir cümle için "Tamamen Katılıyorum", "Katılıyorum", "Kısmen Katılıyorum", "Katılmıorum" ve "Tamamen Katılmıyorum" ifadeleri sırasıyla 5, 4, 3, 2 ve 1 şeklinde puanlandırılmıştır. Verilerin analizinde ise olumlu cümlelerin puanlamaları aynen kalırken, olumsuz cümlelere ait puanlar SPSS'in Recode fonksiyonu kullanılarak ters sırada puanlanmıştır. Tüm veri toplama araçlarından uygulamalardan önce 
ve sonra elde edilen puanların normal dağılım gösterip göstermediğini belirlemek amacıyla Shapiro Wilk testi yapılmış ve verilen normal dağılım göstermediği belirlenmiştir. Bu sebeple verilerin analizinde parametrik olmayan istatistik yöntemleri kullanılmıştır.

Mann Whitney U testi sonuçlarına göre, grupların ön test puanları arasında anlamlı fark bulunmazken, iki aşamalı kavram testi ( $\mathrm{U}=147.500, \mathrm{p}<0.05, \mathrm{z}=-4.018, \mathrm{r}=0.54)$, kimya dersine karşı tutum ölçeği $(\mathrm{U}=105.000, \mathrm{p}<0.05, \mathrm{z}=-4.690, \mathrm{r}=0.63$ ve kimya laboratuvarına karşı tutum ölçeğinden $(\mathrm{U}=201.500, \mathrm{p}<0.05$, $\mathrm{z}=-3.106, \mathrm{r}=0.42$ ) elde edilen son test puanları arasında deney grubu lehine istatistiksel açıdan anlamlı bir farklılık tespit edilmiştir. Ayrıca iki aşamalı kavram testinin ön test uygulamasında belirlenen asitlerin kuvveti, indikatörler, nötralleşme, asitlerin özellikleri, pH, günlük yaşamdaki asitler ve bazlar, çözeltiler, çözünürlük, fiziksel ve kimyasal değişim konularındaki alternatif kavramların yüzdesinde, son testte deney grubunda daha yüksek olmak üzere düşüş belirlenmiştir.

Sonuç olarak karışımlar, fiziksel ve kimyasal değişim, asitler bazlar konusunda uygulanan tahmingözlem-açıklamaya dayalı laboratuvar etkinliklerinin geleneksel yaklaşıma kıyasla, kavramsal anlama, kimya dersine ve kimya laboratuvarına karşı tutum ve alternatif kavramların giderilmesinde daha etkili olduğu belirlenmiştir. Bu sebeple öğretmen eğitiminde laboratuvar etkinliklerinin tahmin-gözlemaçılama gibi aktif öğrenme yöntemleriyle desteklenmesi önerilmektedir. Ayrıca çalışma kapsamında belirlenen alternatif kavramların, geliştirilen etkinliklerin ve iki aşamalı kavram testinin araştırmacılara ve eğitimcilere büyük katkı sağlayacağı düşünülmektedir. 